\title{
EFEKTIVITAS MODEL PEMBELAJARAN KOOPERATIF TIPE TPS-TGT PADA PEMBELAJARAN MATEMATIKADI KELAS VIII SMP N 1 MAKASSAR
}

\author{
Andi Aras \\ E-mail: andiaras@iainpare.ac.id \\ Insitiut Agama Islam Negeri Parepare
}

\begin{abstract}
This type of research is an experimental study which aims to describe the effectiveness of the cooperative learning model TPS-TGT type in mathematics learning in class VIII SMP N 1 Makassar. The sample in this study class VIII.5 was taught by cooperative learning model TPS-TGT type taken using techniques cluster random sampling. The data collected consisted of data on student learning outcomes, data on learners' motivation, data on student activities during the learning process, and data on student responses to the application of cooperative learning models of the TPS-TGT type.

The results showed that the score of mathematics learning outcomes of students in class VIII.5 was in the high category with a mean of 80.15 and a standard deviation of 9.79, completeness in classics was $82.5 \%$, the average normalized gain was in the high category, scores the average learning motivation of students is in the high category, the average gain normalized learning motivation is in the medium category, the activity of students in following the learning process is in a good category, and student responses to the application of the cooperative learning model TPS-TGT type are positive. In general, it was concluded that the cooperative learning model type TPS-TGT was effectively applied to mathematics learning in class VIII.5 of SMP N 1 Makassar.

The results of the hypothesis test at a significant level $\alpha=0.05$ with the t-test show that $\mathrm{HI}$ is accepted which means that the cooperative learning model type TPSTGT is effectively applied to mathematics learning in SPLDV material in class VIII of SMP N 1 Makassar.
\end{abstract}

Keywords: Effectiveness, Cooperative Learning ModelTPS-TGT Type.

\begin{abstract}
ABSTRAK
Jenis penelitian ini adalah penelitian eksperimen yang bertujuan untuk mendeskripsikan keefektifan model pembelajaran kooperatif tipe TPS-TGT pada pembelajaran matematika di kelas VIII SMP N 1Makassar sampel dalam penelitian
\end{abstract}


ini kelas VIII.5 diajar dengan model pembelajaran kooperatif tipe TPS-TGT yang di ambil dengan menggunakan teknik cluster random sampling. Data yang dikumpulkan terdiri atas data hasil belajar peserta didik, data motivasi belajar peserta didik, data aktivitas peserta didik selama mengikuti proses pembelajaran, dan data respons peserta didik terhadap penerapan model pembelajaran kooperatif tipe TPS-TGT.

Hasil penelitian menunjukkan bahwa skor hasil belajar matematika siswa di kelas VIII.5 berada pada kategori tinggi dengan mean 80,15 dan deviasi standar 9,79, ketuntasan secara klasikal sebesar $82,5 \%$, rata-rata gain ternormalisasi berada pada kategori tinggi, skor rata-rata motivasi belajar peserta didik berada pada kategori tinggi, rata-rata gain ternormaliusasi motivasi belajar berada pada kategori sedang, aktivitas siswa dalam mengikuti proses pembelajaran berada pada kategori baik, dan respons siswa terhadap penerapan model pembelajaran kooperatif tipe TPSTGT adalah positif. Secara umum disimpulkan bahwa model pembelajaran kooperatif tipe TPS-TGT efektif diterapkan pada pembelajaran matematika di kelas VIII.5 SMP N 1 Makassar.

Hasil uji hipotesis pada taraf signifikan $\alpha=0,05$ dengan uji-t menunjukkan bahwa $\mathrm{H}_{1}$ diterima yang berarti bahwa model pembelajaran kooperatif tipe TPS-TGT efektif diterapkan pada pembelajaran matematika pada materi SPLDV di kelas VIII SMP N 1 Makassar.

Kata Kunci: Efektivitas, Model Pembelajaran KooperatifTipe TPS-TGT.

\section{PENDAHULUAN}

Dengan adanya rumusan rumusan standar proses pembelajaran matematika, sekolah-sekolah dari sekolah dasar sampai sekolah menengah atas terus berupaya untuk meningkatkan kualitas proses pembelajarannya. Kualitas pembelajaran dapat diukur dengan berbagai macam aspek, di antaranya sejauh mana meningkatnya motivasi belajar peserta didik, tumbuhnya kemampuan interpersonal peserta didik, dan meningkatnya prestasi belajar peserta didik. Motivasi belajar yang di mnaksud adalah motivasi instrinsik yang berkaitan dengan keuletan $^{1}$, ketekunan ${ }^{2}$, dan optimisme $^{3}$, kesenangan ${ }^{4}$, minat $^{5}$, dan komitmen ${ }^{6}$ peserta didik, baik dalam

\footnotetext{
${ }^{1}$ Wheeler, P.A. The importance of interpersonal skills. (2005). h. 44.

${ }^{2}$ Hook, P. \& Vass, A. Creating Winning classroom. London: Davis Fulton Publishers. (2001). h.

65. Lihat juga Wheeler, P.A. The importance of interpersonal skills. (2005). h. 44.

${ }^{3}$ lihat Wheeler, P.A.. (2005). h. 44.

${ }^{4}$ Santrock, J.W. Educational psychology (5th ed.). New York: McGraw-Hill Companies, Inc. (2011). h. 441
} 
menghadapi tugas-tugas mandiri pembelajaran matematika, menghadapi tugas atau latihan di kelas, dan menghadapi ulangan. Selanjutnya, aspek kemampuan interpersonal peserta didik (interpersonal skills) yaitu kemampuan peserta didik yang berkaitan dengan aspek-aspek antara lain toleran dengan keberagaman ${ }^{7}$, kerjasama ${ }^{8}$, empati terhadap orang lain ${ }^{9}$, komunikasi yang baik dan menyelesaikan masalah/konflik ${ }^{10}$, sehingga dapat memperoleh hasil terbaik dan mencapai tujuan dalam pembelajaran matematika. Sedangkan aspek prestasi belajar berkaitan dengan skor yang dicapai peserta didik dalam bentuk tes pada aspek kognitif setelah mengikuti kegiatan pembelajaran.

Kenyataan di lapangan khususnya dalam pembelajaran matematika, efektivitas pembelajaran dilihat dari aspek motivasi belajar, kemampuan interpersonal, dan prestasi belajar peserta didik masih perlu mendapat perhatian. Beberapa hasil temuan di kelas berdasarkan hasil observasi di SMPN 1 Makassar di antaranya: salah satu model pembelajaran yang digunakan oleh guru mata pelajaran matematika saat mengajar di kelas adalah terkadang menggunakan model pembelajaran langsung dengan metode ceramah, kemudian dilanjutkan dengan mencatat dan latihan soal-soal yang sudah disediakan,penggunaan model pembelajaran langsung terlihat masih berlangsung satu arah, karena kegiatan pembelajaran terpusat pada guru.. Dengan metode tersebut, peserta didik yang belum memahami dengan baik topik tersebut kurang terdeteksi dengan baik oleh guru. Selain itu, peserta didik kurang terlatih dalam mengembangkan ide-idenya dalam menyelesaikan masalah dan kurang termotivasi dalam mengikuti proses pembelajaran. Persoalan-persoalan tersebut berdampak pada hasil belajar matematika peserta didik yang masih tergolong rendah dan belum tuntas secara klasikal.

Model pembelajaran yang dapat dipilih sebagai alternatif dalam penelitian ini yang diduga mampu menumbuhkan dan meningkatkan prestasi belajar, motivasi belajar, dan kemampuan interpersonal peserta didik adalah pembelajaran

\footnotetext{
${ }^{5}$ Brophy, J. Motivation students to learn (2nd ed.). Mahwah, NJ: Lawrence Erlbaum Associates Publishers. (2004). h. 4

${ }^{6}$ Cohen, R.J., \& Swedlik M.E. Psychological testing and assessment: an introduction to test and measurement (6th ed.). New York. McGraw-Hill Companies. (2005). h. 550

${ }^{7}$ Gillies, R.M. Cooperative learning: integrating theory and practice. Los Angeles: SAGE Publications (2007). Lihat juga Koenig, J.A. Assessing 21 st century skills: summary of a workshop. Washington, DC: The National Academies Press. (2011). h. 41

${ }^{8}$ Koenig, J.A. Assessing 21 st century skills: summary of a workshop. Washington, DC: The National Academies Press. (2011). h. 2. Lihat juga Barron, M. \& Barron, A.R. Project management areas of expertise. (2009). h. 4

${ }^{9}$ Lihat Koening (2011) h. 2

${ }^{10}$ Lihat Barron (2009) h. 4
} 
kooperatif. Pembelajaran kooperatif merupakan strategi yang efektif untuk membantu pencapaian peserta didik dalam arti luas baik secara akademis maupun sosial, termasuk pencapaian prestasi, peningkatan keyakinan diri, meningkatkan hubungan yang baik peserta didik dengan peserta didik lain ${ }^{11}$.

Model pembelajaran kooperatif tipe TPS-TGT merupakan hasil kombinasi dari TPS dengan TGT. Think Pair Share (TPS) merupakan suatu cara yang efektif untuk membuat variasi suasana pola diskusi kelas dengan asumsi bahwa diskusi membutuhkan pengaturan untuk mengendalikan kelas secara keseluruhan dan dapat memberi waktu yang banyak pada peserta didik untuk lebih banyak berpikir, merespon, dan saling membantu. Guru menginginkan peserta didik mempertimbangkan lebih banyak apa yang telah dijelaskan dan dialami untuk membandingkan tanya jawab kelompok keseluruhan ${ }^{12}$. (Trianto, 2011: 81).Model pembelajaran TGT merupakan salah satu model kooperatif dimana peserta didik ditempatkan dalam tim dengan kemampuan yang heterogen untuk berkompetisi dalam game tournament. Model pembelajaran TGT memiliki tiga elemen dasar yaitu tim, permainan, dan turnamen ${ }^{13}$. Model pembelajaran kooperatif tipe TGT dalam penerapannya melibatkan peserta didik aktif dalam belajar dan bermain bersama kelompoknya. Di dalam kombinasi model pembelajaran kooperatif tipe Think Pair Share (TPS) dengan Teams Games Tournament (TGT) peserta didik ditempatkan dalam kelompok, yang awalnya kelompok kecil berjumlah dua orang menjadi empat orang yang heterogen. Di dalam kelompok, peserta didik aktif bekerjasama dan berinteraksi dengan peserta didik lain, bertanggungjawab terhadap tugas yang diberikan guru baik secara individu maupun kelompoknya sehingga dapat memahami materi dengan baik, Kompetisi dalam game tournament diharapkan peserta didik dapat memiliki rasa tanggungjawab dalam menguasai materi matematika.

Berdasarkan latar belakang di atas, maka rumusan masalah dalam penelitian ini adalah apakah model kooperatif tipe TPS-TGT efektif diterapkan dalam pembelajaran matematika pada materi SPLDV di kelas VIII SMP N 1 Makassar?

\footnotetext{
${ }^{11}$ Killen, R. Effective teaching strategies: lessons from research and practice (5th ed.). South Melbourne: Cengage Learning Australia. (2009). h. 216. Lihat juga Effandi, Zakaria. 2007. Promoting Cooperatif Learning In Science and Mathematics Education: A Malaysian Perspective. Eurasia Journal of Mathematics, Science \& Technology Education, 3(1), hal. 35-39.

${ }^{12}$ Trianto. Mendesain Model Pembelajaran Inovatif-Progresif. Jakarta: Kencana Prenada Media Group. (2011). h. 124.

${ }^{13}$ Grabowski, Barbara, dan Fengfeng, K.. Gameplaying for maths learning: cooperative or not. British Journal of Educational Technology. (2007) h. 250.
} 


\section{METODE PENELITIAN}

Penelitian ini dikategorikan sebagai penelitian eksperimen yang bertujuan membangun Model Pembelajaran kooperatif tipe TPS-TGT dan menguji keefektifannya dalam pembelajaran matematika.

\section{Desain Penelitian}

Desain dalam penelitian ini adalah the One-Group Pretest-Posttest design. Berikut adalah model desainnya.

Tabel 2. 1 Model Desain Penelitian

\begin{tabular}{|c|c|c|}
\hline Pretest & Perlakuan & Posttest \\
\hline $\mathrm{O}_{1}$ & $\mathbf{X}$ & $\mathrm{O}_{2}$ \\
\hline
\end{tabular}

\section{Populasi dan Sampel}

Populasi dalam penelitian ini adalah semua peserta didik kelas VIII SMP N 1 Makassar tahun pelajaran 2016/2017 yang berjumlah 375 siswa dan tersebar pada sepuluh kelas. Teknik pemilihan sampel yang digunakan dalam penelitian ini adalah cluster random sampling di mana sampel penelitian adalah kelas VIII.5 yang di ajar dengan menggunakan model pembelajaran kooperatif tipe TPS-TGT .

\section{PEMBAHASAN}

\section{Analisis Keefektifan Penerapan Model Pembelajaran Kooperatiftipe TPS-} TGT pada Pembelajaran Matematika di Kelas VIII. 5 SMP N 1 Makassar

Berdasarkan hasil analisis data diperoleh bahwa skor rata-rata hasil posttest siswa yang di ajar dengan penerapan model kooperatif tipe TPS-TGT yaitu 80,15 (tinggi), N-gain hasil belajar adalah 0,78 (tinggi)dengan ketuntasan klasikal hasil belajar sebesar $82,5 \%$. Skor rata-rata total motivasi belajar siswa adalah 4,45 (tinggi) dan peningkatan motivasi belajar siswa sebesar 0,42 (sedang). Skor ratarata aktivitas siswa yaitu 4,43 (aktif) dan skor rata-rata total respon siswa yaitu 4,23 (positif).

Berdasarkan hasil analisis inferensial posttest hasil belajar diperoleh nilai pvalue $=0.000$, dengan menggunakan alpha $(\alpha)=0.05(5 \%)$ yang artinya nilai $\mathrm{p}$ value $<\alpha$, sehingga dilakukan penerimaan $H_{1}, \mathrm{~N}$-gain hasil belajar diperoleh nilai $\mathrm{p}$ value $=0.000$, dengan menggunakan alpha $(\alpha)=0.05(5 \%)$ yang artinya nilai $\mathrm{p}$ value $<\alpha$ sehingga dilakukan penerimaan $H_{1}$, Pengujian ketuntasan klasikal peserta didik dilakukan dengan menggunakan uji proporsi. Untuk uji proporsi dengan menggunakan taraf signifikan 5\% di peroleh $\mathrm{Z}$ tabel $=1,64$, untuk uji hipotesis pihak kanan, $\mathrm{H}_{0}$ diterima jika $\mathrm{Z} \leq \mathrm{Z}_{(0,5-\alpha)}$, dan $\mathrm{H}_{0}$ ditolak jika $\mathrm{Z}>\mathrm{Z}_{(0,5-\alpha) \text {. Dari hasil }}$ 
perhitungan diperoleh nilai $\mathrm{Z}$ hitung $=0,54$, dengan demikian cukup bukti untuk menerima $\mathrm{H}_{0}$. Artinya proporsi siswa yang mencapai criteria ketuntasan 75 adalah tidak lebih dari $80 \%$ dari keseluruhan siswa yang mengikuti tes. Analisis motivasi belajar siswa diperoleh nilai $\mathrm{p}$-value $=0.000$, dengan menggunakan alpha $(\alpha)=$ $0.05(5 \%)$ yang artinya nilai p-value $<\alpha$ sehingga dilakukan penerimaan $H_{1}$, analisis peningkatan motivasi belajar siswa diperoleh nilai p-value $=0.000$, dengan menggunakan alpha $(\alpha)=0.05(5 \%)$ yang artinya nilai $\mathrm{p}$-value $<\alpha$, sehingga dilakukan penerimaan $H_{1}$. Analis respons siswa diperoleh nilai p-value $=0.000$, dengan menggunakan alpha $(\alpha)=0.05(5 \%)$ yang artinya nilai $\mathrm{p}$-value $<\alpha$, sehingga dilakukan penerimaan $H_{1}$.

Berdasarkan hasil analisis deskriptif dan hasil analisis inferensial yang telah diuraikan, tampak bahwa model pembelajaran kooperatif tipe TPS-NHT telah memenuhi kriteria keefektifan, baik dari hasil belajar, motivasi belajar, aktivitas peserta didik, dan respons peserta didik. Oleh karena itu, hipotesis mayor 1 teruji kebenarannya sehingga dapat disimpulkan bahwa model pembelajaran koopereatif tipe TPS-NHT efektif diterapkan dalam pembelajaran matematika di kelas VIII.4 SMP N 1 Makassar.Keefektifan penerapan model pembelajara kooperatif tipe TPSNHT disebabkan karena adanya kombinasi antara dua model kooperatif yakni Think Pair Share (TPS) dan Numbered Heads Togethers (NHT). Dimana model kooperatif Think Pair Share mampu merangsang aktivitas berpikir peserta didik secara mandiri dan berpasangan yang kemudian berbagi pengetahuan dengan seluruh siswa untuk pemecahan masalah bersama. Sementara model kooperatif Numbered Heads Togethers menumbuhkan rasa tanggung jawab peserta didik dalam belajar sehingga mereka akan lebih termotivasi dalam mengikuti proses pembelajaran.

Berdasarkan hasil analisis deskriptif dan hasil analisis inferensial yang telah diuraikan, tampak bahwa model pembelajaran kooperatif tipe TPS-TGT telah memenuhi kriteria keefektifan, baik dari hasil belajar, motivasi belajar, aktivitas peserta didik, dan respons peserta didik. Oleh karena itu, hipotesis mayor 2 teruji kebenarannya sehingga dapat disimpulkan bahwa model pembelajaran koopereatif tipe TPS-TGT efektif diterapkan dalam pembelajaran matematika di kelas VIII.5 SMP N 1 Makassar. Keefektifan penerapan model pembelajara kooperatif TPSTGT disebabkan karena adanya kombinasi antara dua model kooperatif yakni Think Pair Share (TPS) dan Teams Games Tournamnet (TGT). Dimana model kooperatif Think Pair Share mampu merangsang aktivitas berpikir peserta didik secara mandiri dan berpasangan yang kemudian berbagi pengetahuan dengan seluruh siswa untuk pemecahan masalah bersama. Sementara model kooperatif Teams Games Tournamnet menumbuhkan rasa tanggung jawab peserta didik dalam 
belajar, rasa percaya diri dan minat siswa belajar menjadi lebih tinggi sehingga mereka akan lebih termotivasi dalam mengikuti proses pembelajaran.

Model pembelajaran kooperatif tipe TPS-TGT pada dasarnya penulis rancang untuk memberikan kesempatan kepada peserta didik untuk saling membantu satu sama lain guna mencapai hasil belajar yang maksimal. Adanya pembelajaran yang dilakukan antara peserta didik yang berkemampuan tinggi kepada peserta didik yang berkemampuan rendah secara bersama-sama akan membentuk penstrukturan kognitif dalam tutorial teman sebaya. Model pembelajaran ini di dalam sintaks pembelajarannya menitihberatkan adanya kompetisi kognitif yang akan membuat siswa lebih aktif dalam proses pembelajaran serta memiliki rasa tanggung jawab kepada teman kelompoknya untuk menjadi yang terbaik sehingga mereka akan termotivasi dalam mengikuti proses pembelajaran.

Tabel 3.1 Pencapaian Efektivitas Model Pembelajaran Kooperatif Tipe TPS-TGT

\begin{tabular}{|c|c|c|c|c|c|}
\hline No & Model Pembelajaran & Indikator & Kriteria & Pencapaian & Keputusan \\
\hline 1 & $\begin{array}{l}\text { Model pembelajaran } \\
\text { kooperatif tipe TPS-TGT } \\
\text { Efektif diterapkan dalam } \\
\text { Pembelajaran Matematika } \\
\text { di Kelas VIII.5 SMP N } 1 \\
\text { Makassar }\end{array}$ & 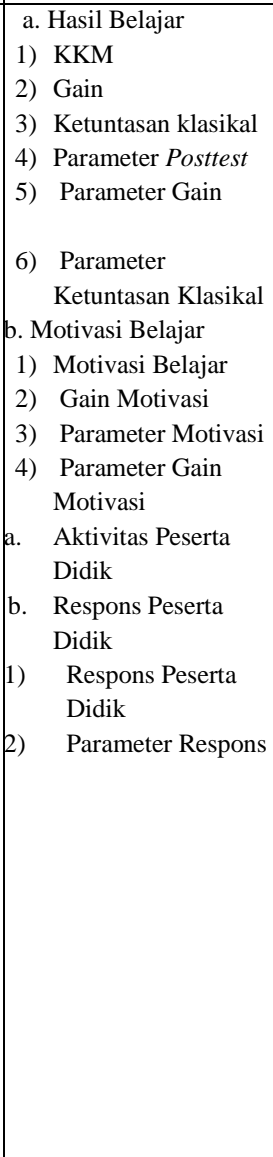 & $\begin{aligned} & \bar{x}_{2}>74,9 \\
& \bar{x}_{2}>0,29 \\
& \mathrm{KK}_{2}>79,9 \% \\
& \mu_{2}>74,9 \\
& \mu_{\mathrm{g} 2}>0,29 \\
& \pi_{2}>79,9 \% \\
& \bar{M}_{2}>2,49 \\
& \bar{M}_{2}>0,29 \\
& \mu_{\mathrm{m} 2}>2,49 \\
& \mu_{\mathrm{gm} 2}>0 \\
& \bar{A}_{2}>3,49 \\
& \bar{R}_{2}>3,49 \\
& \mu_{\mathrm{r} 2}>3,49\end{aligned}$ & $\begin{array}{c}80,15 \\
0,78 \\
82,5 \% \\
\text { Signifikan } \\
\text { Signifikan } \\
\text { Tidak Signifikan } \\
4,24 \\
0,34 \\
\text { Signifikan } \\
\text { Signifikan } \\
4,43 \\
4,23 \\
\text { Signifikan }\end{array}$ & $\begin{array}{l}\text { Terpenuhi } \\
\text { Terpenuhi } \\
\text { Terpenuhi } \\
\text { Terpenuhi } \\
\text { Terpenuhi } \\
\text { Terpenuhi } \\
\text { Terpenuhi }\end{array}$ \\
\hline
\end{tabular}




\section{KESIMPULAN}

Berdasarkan hasil penelitian dan pembahasan yang diperoleh, maka kesimpulan dari hasil penelitian ini adalah sebagai berikut:

1. Model pembelajaran kooperatif tipe TPS-TGT efektif diterapkan dalam pembelajaran matematika pada materi SPLDV di kelas VIII.5 SMP N 1 Makassar.

a. Skor hasil belajar matematika siswa di kelas VIII.5 berada pada kategori tinggi dengan mean 80,15 dan deviasi standar 9,79, ketuntasan secara klasikal sebesar $82,5 \%$, rata-rata gain ternormalisasi adalah 0,78 berada pada kategori tinggi.

b. Skor rata-rata motivasi belajar peserta didik 4,24 berada pada kategori tinggi, rata-rata gain ternormaliusasi motivasi belajar 0,34 berada pada kategori sedang.

c. Aktivitas siswa dalam mengikuti proses pembelajaran adalah 4,43 berada pada kategori baik.

d. Respons siswa terhadap penerapan model pembelajaran kooperatif tipe TPS-TGT adalah 4,23 berada pada kategori positif.

\section{DAFTAR PUSTAKA}

Adam, Barragato. 2015. Think/ Pair/ Share and Variations. Central Michigon University: Faculty Center for Innovative Teaching.

Adeneye., Alfred., \& Samuel Adejare. 2012. Achievement in Cooperative versus Individualistic Goal-Structured Junior Secondary School Mathematics Classrooms in Nigeria. International Journal of Mathematics Trends and Technology-Volume3 Issue1

Arends, Ricards. 1998. Eksploring Teaching an Intruduction to Education. New York: McGraw-Hill

Azlina, N.A.N. (2010). CETLs: Supporting Collaborative Activities Among Students and Teachers Through the Use of Think-Pair-Share Techniques. IJCSI International Journal of Computer Science.7 (5), Juli 2016.

Baker, Paul, Daniel. 2013. The Effects of Implementing The Cooperative Learning Structure, Numbered Heads Together In Chemistry Closses At A Rural Low Performing High School. A Thesis. Louisiana: B.S Lousiana State University. Brophy, J. (2004). Motivation students to learn (2nd ed.). Mahwah, NJ: Lawrence Erlbaum Associates Publishers. 
Cohen, R.J., \& Swedlik M.E. (2005). Psychological testing and assessment: an introduction to test and measurement (6th ed.). New York. McGraw-Hill Companies.

Effandi, Zakaria. 2007. Promoting Cooperatif Learning In Science and Mathematics Education: A Malaysian Perspective. Eurasia Journal of Mathematics, Science \& Technology Education, 3(1), hal. 35-39 (www.ejmste.com.Diakses 20 Juli 2016).

FirdhaRazak. 2016. The Effect of Cooperatif Learning on Mathematics Learning Outcomes Viewed from Students' Learning Motivation. Journal of Research and Advances in Mathematics Education ISSN: 2503-3697 (Print) Vol. 1, No. 1, 49-55, January 2016 http://journals.ums.ac.id/index.php/jramathedu, Diakses23 Juli 2016).

Gillies, R.M. (2007). Cooperative learning: integrating theory and practice. Los Angeles: SAGE Publications.

Grabowski, Barbara, dan Fengfeng, K. 2007. Gameplaying for maths learning: cooperative or not?. British Journal of Educational Technology. vol. 38, no. 2, hlm. 249-259.

Hayes, J. (2002). Interpersonal skills: goal-directed behavior at work. New York: Routledge.

Hook, P. \& Vass, A. (2001). Creating Winning classroom. London: Davis Fulton Publishers.

Killen, R. (2009). Effective teaching strategies: lessons from research and practice (5th ed.). South Melbourne: Cengage Learning Australia.

Koenig, J.A. (2011). Assessing 21st century skills: summary of a workshop. Washington, DC: The National Academies Press.

Kyriacou, C. (2009). Effective teaching in schools (3rd ed). London: Stanley Thornes.

Santrock, J.W. (2011). Educational psychology (5th ed.). New York: McGraw-Hill Companies, Inc.

Sardiman. 2010. Interaksi dan motivasi belajar mengajar. Jakarta: Rajawali Pers.

Slavin. R., E. 2005. Cooperative Learning Teori, Riset dan Praktik. Bandung: Nusa Media.

Sugiarto. 2012. Teknik Sampling, Gramedia, Jakarta.

Trianto.2011. Mendesain Model Pembelajaran Inovatif-Progresif. Jakarta: Kencana Prenada Media Group. 